\title{
ANALISIS TEGANGAN PIPA 043-GN-31004 PADA SCRUB COLOUMN VESSEL MENUJU VESSEL COLOUMN PROYEK TANGGUH EXPANSION TRAIN 3 PAPUA
}

\author{
Ahmad Husen ${ }^{1}$, Aldi Setiyadi ${ }^{2}$, Nur Cholis ${ }^{3}$ \\ 1, 2 Program Studi Teknik Mesin, Institut Sains dan Teknologi Nasional, Jakarta Selatan \\ ${ }^{3}$ Program Studi Teknik Mesin, Universitas Pembangunan Nasional "Veteran" Jakarta, Jakarta Selatan \\ Email²: aldi.setiadi87@gmail.com
}

\begin{abstract}
In this research will be discussed about the analysis of pipeline system voltage in a tough project on line 043-GN-31004 / T08 where the fluid flowing in the pipe fluctuates at pressure and temperature every day and required a voltage calculation analysis to ensure the pipeline has been installed and pedestal pipe that is placed right in place so that the stress (stress) that occurs does not exceed the maximum limit of voltage limitation set by the code / standard ASME B31.3. The result of stress calculation analysis due to the maximum Sustain load is at node 88 in CAESAR II program 171.999 Kpa and manual calculation is 245527.7 Kpa with calculation deviation of $12.34 \%$. So that the calculation does not exceed the allowed limit code / standard ASME B31.3, and due to fluid fluctuations in terms of pressure and temperature causing the pipe to change erratically every day then at node 88 need to be re-planning by adding more buffer flexible so that it can follow the change of pipe, so it can be concluded that the pipeline system in Tangguh Expansion Train - 3 project does not happen overstress and safe to operate. Keywords: Sustain, Expansion, Code /Standard, Piping System, Voltage, ASME B31.3
\end{abstract}

Keywords: ASME B31.3, Piping system, Stress analysis, Sustain, Expansion, Code/Standard.

\section{PENDAHULUAN}

\section{Latar Belakang Masalah}

Oil and Gas adalah suatu site yang memproduksi minyak dan gas alam berupa produk LNG (Liquefied Natural Gas), LPG (Liquefied Petrolium Gas), Gasoline (BBM), Fuel Jet (Avtur), Diesel Fuel (Solar). Oil and Gas site tidak akan terlepas dari desain perpipaan berfungsi sebagai media penyalur fluida dari equipment ke equipment lain. Dalam tahap perancangan sistem perpipaan perlu dilakukan perhitungan yang tepat, untuk menjaga agar sistem perpipaan aman pada waktu beroperasi.

Penyebab timbulnya daerah kritis (critical line) antara lain karena diameter pipa yang besar, fluida kerja bersuhu dan bertekanan tinggi. Efek yang dapat timbul pada jalur kritis akan terjadi kegagalan pada material. Standar yang digunakan sebagai acuan dalam perhitungan analisa tegangan adalah ASME B31.32014.

Critical line yang akan dibahas pada penelitian ini adalah jalur perpipaan Gas alam cair (Natural Gas) dari Scrub Coloumn Reboiler menuju Vessel Coloumn pada unit area proses 043. Kendala yang terjadi pada fase desain perencanaan adalah posisi nosel pada tanki yang sudah terfabrikasi dan tidak ada kemungkinan untuk di fabrikasi ulang. sehingga jalur pipa ini harus mengikuti posisi nosel yang sudah ada. Akibat dari kejadian tersebut maka harus dilakukan analisa kembali dan menambahkan penyanggah pada pipa serta melakukan perencanaan ulang jalur pipa (Redesign) untuk mempertahankan fleksibilitas pipa tersebut agar tidak terjadi overstress.

\section{Perumusan Masalah}

Dalam penelitian ini penulis merumuskan masalah sebagai berikut:

1. Akibat kenaikan suhu yang berubah-ubah setiap hari maka dapat terjadi overstress pada sistem perpipaan akibat beban expansion thermal sehingga diperlukan atau tidaknya penambahan berupa penyangga pada jalur pipa itu. Terjadinya muai panas pada pipa saat pipa dilalui oleh fluida Two Phase yang mengakibat pipa mengalami pergeseran dari kondisi awal.

2. Terjadinya muai panas pada pipa saat pipa dilalui oleh fluida Two Phase yang mengakibat pipa mengalami pergeseran dari kondisi awal.

\section{Batasan Masalah}

Dalam penelitian ini penulis membatasi masalah sebagai berikut:

1. Perhitungan overstress pada sistem perpipaan mengacu pada standar ASME B31.3 dengan penyesuaian desain sistem 
perpipaan berdasarkan muai panas yang dialami pipa saat dialiri fluida Two Phase.

2. Perhitungan hanya dilakukan pada line number 043-GN-31004. Yang dilakukan pada area 043 Hot Area proyek Tangguh Expansion Train - 3 .

3. Perhitungan analisa sistem perpipaan ini dilakukan dengan menggunakan program CAESAR II 2014 versi 7.0, sehingga didapat hasil perhitungan gaya, momen, tegangan dan panjang ekspansi pipa pada jalur perpipaan dalam bentuk angka yang dapat ditabelkan.

\section{Maksud dan Tujuan}

Dari latar belakang dan perumusan masalah yang telah penulis sampaikan maka dimaksudkan:

1. Memahami dan mengerti tentang standard ASME B31.3 yang digunakan untuk merancang dan menganalisa sistem perpipaan.

2. Memberikan manfaat berupa upaya perbaikan untuk mengantisipasi dan mengurangi terjadinya overstress pada sistem perpipaan.

Sedangkan tujuan dari penelitian sebagai berikut:

1. Menganalisisa seberapa besar tingkat overstress pada sistem perpipaan akibat beban expansion thermal agar tegangan didalam pipa tetap dalam batasan ASME B31.3.

2. Memastikan penyangga/support yang telah ditambahkan bisa mengurangi tegangan pada sistem perpipaan akibat fluktuasi fluida.

3. Dapat memastikan bahwa jalur pipa tersebut aman dan apabila ada tegangan yang kritis dapat memberikan solusi yang terbaik sehingga tegangan yang berlebih dapat dicegah.

\section{TINJAUAN PUSTAKA}

\section{Teori Dasar Tegangan Pipa}

Dalam menerapkan kode standar desain, kita harus mengerti prinsip dasar dari tegangan pipa dan halhal yang berhubungan dengannya. Sebuah pipa dinyatakan rusak jika tegangan dalam yang terjadi pada pipa melebihi tegangan batas material yang diizinkan. Dari definisi yang sederhana ini ada dua buah istilah yang harus dipahami dengan benar yaitu tegangan dalam pipa dan tegangan batas yang diizinkan. ${ }^{1}$

Tegangan dalam yang terjadi pada pipa di sebabkan oleh tekanan dari dalam pipa, beban luar seperti berat mati dan pemuaian thermal, dan bergantung pada bentuk geometri pipa serta jenis material pipa. Sedangkan tegangan batas lebih banyak di tentukan oleh jenis material dan metode produksinya.

Dalam pembahasan kode standar ini kita harus membedakan pengertian tegangan pipa menjadi:

1. Tegangan pipa aktual, yaitu tegangan hasil pengukuran dengan strain gauge atau perhitungan analisis secara manual maupun dengan piranti lunak komputer.

2. Tegangan pipa kode, yaitu tegangan hasil perhitungan dengan menggunakan persaman tegangan yang tertera dalam kode standar tertentu.

Tegangan adalah besaran vektor yang selain memiliki nilai juga memerlukan arah. Nilai dari tegangan di definisikan sebagai gaya $(F)$ per satuan luas $(A)$. Untuk mendefinisikan arah pada tegangan pipa, sebuah sumbu prinsip pipa di buat saling tegak lurus seperti yang ditunjukkan pada Gambar 2.1 di bawah ini:

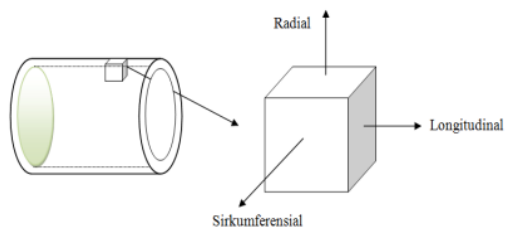

Gambar 2.1. Arah pada tegangan pipa

(Sumber: Jamaludin, Achmad, Jurnal 2016, Analisis Tegangan Sistem Perpipaan Pada Sisi Tekan Pompa P003E Menggunakan Caesar II dan Perhitungan Manual, hal 5)

Sumbu terletak di bidang tengah dinding pipa dan yang salah satu arahnya sejajar dengan panjang pipa disebut sumbu aksial atau longitudinal. Sumbu yang tegak lurus terhadap dinding pipa dengan arahnya bergerak dari pusat pipa menuju luar pipa disebut sumbu radial. Sumbu yang sejajar dengan dinding pipa tetapi tegak lurus dengan sumbu aksial disebut sumbu tangensial atau sirkumferensial.

\section{Ragam Tegangan}

Tegangan yang tejadi dalam sistem perpipaan dapat dikelompokkan ke dalam dua kategori, yakni Tegangan Normal (Normal Stress) dan Tegangan Geser (Shear Stress).

Tegangan normal terdiri dari tiga komponen tegangan, yang masing-masing adalah:

1. Tegangan Longitudinal (Longitudinal Stress), yaitu tegangan yang searah panjang pipa.

2. Tegangan Tangensial atau Tegangan Keliling (Circumferential Stress atau Hoop Stress), yaitu tegangan yang searah garis singgung penampang pipa,

3. Tegangan Radial (Radial Stress), yaitu tegangan searah jari-jari penampang pipa.

Tegangan Geser terdiri dari dua komponen tegangan, yang masing-masing adalah:

1. Tegangan Geser (Shear Stress), yaitu tegangan akibat gaya geser,

2. Tegangan Puntir atau Tegangan Torsi (Torsional Stress), yaitu tegangan akibat momen puntir pada pipa. 


\section{Tegangan Longitudinal}

Tegangan longitudinal $\left(S_{L}\right)$ atau tegangan aksial adalah tegangan yang arahnya sejajar dengan sumbu longitudinal. Nilai tegangan ini akan dinyatakan positif jika tegangan yang terjadi adalah tegangan tarik dan negatif jika tegangannya berupa tegangan tekan. Tegangan Longitudinal merupakan jumlah dari Tegangan Aksial (Axial Stress), Tegangan Tekuk (Bending Stress) dan Tegangan Tekanan (Pressure Stress). Mengenai ketiga tegangan ini dapat diuraikan berikut ini.

Tegangan Aksial $\left(\boldsymbol{S}_{a x}\right)$ adalah tegangan yang ditimbulkan oleh gaya $F_{a x}$ yang bekerja searah dengan sumbu pipa seperti terlihat pada Gambar 2.2. Nilai dari tegangan aksial dapat dirumuskan sebagai berikut.

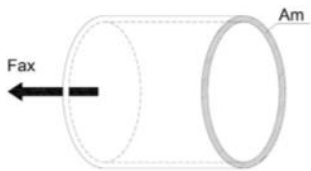

Gambar 2.2. Tegangan aksial

(Sumber: Jamaludin, Achmad, Jurnal 2016, Analisis Tegangan Sistem Perpipaan Pada Sisi Tekan Pompa P003E Menggunakan Caesar II dan Perhitungan Manual, hal 7)

$$
S_{a x}=\frac{F_{a x}}{A_{m}}=\frac{P \cdot A_{i}}{\pi \cdot d_{m} \cdot t}=\frac{P \cdot A_{i}}{\frac{\pi}{4}\left(d_{o}{ }^{2}-d_{i}{ }^{2}\right)}
$$

Tegangan Tekuk $\left(S_{B}\right)$ adalah tegangan yang ditimbulkan oleh momen $(M)$ yang bekerja diujungujung pipa. Tegangan tekuk maksimum terjadi pada permukaan pipa sedangkan tegangan minimum terjadi pada sumbu pipa seperti terlihat pada Gambar 2.3. Nilai dari tegangan tersebut dapat dirumuskan sebagai berikut.

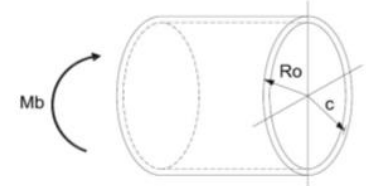

Gambar 2.3. Tegangan Tekuk

(Sumber: Jamaludin, Achmad, Jurnal 2016, Analisis Tegangan Sistem Perpipaan Pada Sisi Tekan Pompa P003E Menggunakan Caesar II dan Perhitungan Manual, hal 7)

$$
S_{B}=\frac{M_{b} \cdot c}{I}=\frac{M_{b} \cdot R_{o}}{I}=\frac{M_{b}}{Z}
$$

Tegangan Tekan $\left(S_{P}\right)$ adalah tegangan yang ditimbulkan oleh gaya tekan internal $(P)$ yang bekerja pada dinding pipa dan searah sumbu pipa seperti terlihat pada Gambar 2.4. Nilai tegangan tersebut dapat dirumuskan sebagai berikut.

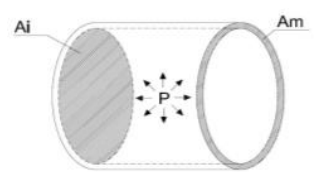

Gambar 2.4. Tegangan Tekan

(Sumber: Jamaludin, Achmad, jurnal 2016, Analisis Tegangan Sistem Perpipaan Pada Sisi Tekan Pompa P003E Menggunakan Caesar II dan Perhitungan Manual, hal 10.)

Dengan demikian tegangan longitudinal secara keseluruhan adalah jumlah dari gaya aksial + tekanan dalam pipa + bending momen pipa, sehingga dapat dituliskan seperti persamaan berikut ini:

$$
S_{L}=\frac{F_{a x}}{A_{m}}+\frac{P . d_{o}}{4 t}+\frac{M_{b}}{Z}
$$

\section{Tegangan Tangensial}

Tegangan ini disebabkan oleh tekanan dalam pipa dimana tekanan ini bersumber dari fluida dan nilainya selalu positif jika tegangan cenderung membelah pipa menjadi dua. Tekanan dalam ini bekerja kearah tangensial dan besarnya bervariasi terhadap tebal dinding dari pipa, nilai tekanan yang diberikan kepada dinding pipa atau nilai tekanan yang dialami dinding pipa sama dengan tekanan yang diberikan oleh fluida. Rumus untuk tegangan tangensial dapat didekati dengan memakai persamaan berikut.

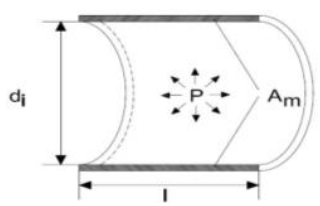

Gambar 2.5. Tegangan Tangensial

(Sumber: Jamaludin, Achmad, jurnal 2016, Analisis Tegangan Sistem Perpipaan Pada Sisi Tekan Pompa P003E Menggunakan Caesar II dan Perhitungan Manual, hal 9)

$$
S_{H}=\frac{P . d_{o}}{2 . t}
$$

\section{Tegangan Radial}

Tegangan radial adalah tegangan yang bekerja pada dalam arah radial pipa atau jari-jari pipa. Nilai dari tegangan radial yang ditimbulkan karena adanya tekanan dari dalam pipa yang bervariasi pada dinding dalam pipadan dinding luar pipa. Nilai tegangan radial terbesar (maksimum) terjadi pada dinding dalam pipa, sedangkan nilai tegangan redial terkecil (minimum) terjadi pada dinding luar pipa. ${ }^{2}$ 


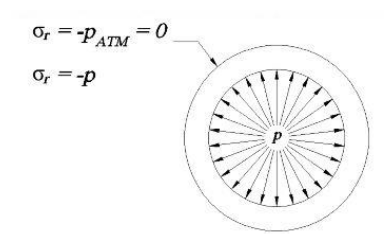

Gambar 2.6. Tegangan Radial

(Sumber: Jamaludin, Achmad, jurnal 2016, Analisis Tegangan Sistem Perpipaan Pada Sisi Tekan Pompa P003E Menggunakan Caesar II dan Perhitungan Manual, hal 10)

$$
S_{R}=\frac{P \cdot r_{i}^{2}}{r_{o}{ }^{2}-r_{i}^{2}}\left(1-\frac{r_{o}^{2}}{r^{2}}\right)
$$

\section{Tegangan Geser}

Tegangan geser adalah tegangan yang arahnya paralel dengan penampang-permukaan pipa yang terjadi jika dua atau lebih tegangan normal yang diuraikan di atas bekerja pada satu titik. Tegangan geser pada sistem perpipaan antara lain akibat gaya dari tumpuan pipa (pipe support) dikombinasikan dengan gaya tekuk.

\section{a. Akibat Gaya Geser V}

Tegangan ini maksimum di sumbu netral (sumbu simetri pipa) dan tidak bernilai pada titik di mana tegangan lendut maksimum (pada permukaan luar dinding pipa). Akibat hal ini dan besar tegangan ini biasanya sangat kecil, maka tegangan ini diabaikan seperti terlihat pada Gambar 2.7 dibawah ini.

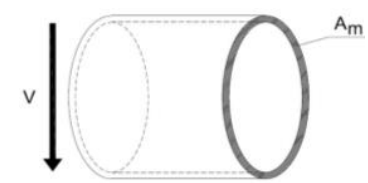

Gambar 2.7. Tegangan Geser

(Sumber: Jamaludin, Achmad, Jurnal 2016, Analisis Tegangan Sistem Perpipaan Pada Sisi Tekan Pompa P003E Menggunakan Caesar II dan Perhitungan Manual)

$$
\tau_{\max }=\frac{V \cdot Q}{A_{m}}
$$

\section{b. Akibat Momen Puntir}

Tegangan ini maksimum pada titik yang sama dimana tegangan lendut maksimum seperti terlihat pada Gambar 2.8 dibawah ini.

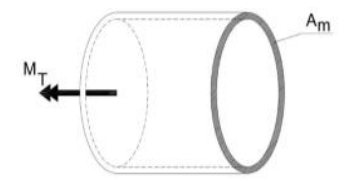

Gambar 2.8. Tegangan Puntir

(Sumber: Jamaludin, Achmad, Jurnal 2016, Analisis Tegangan Sistem Perpipaan Pada Sisi Tekan Pompa P003E Menggunakan Caesar II dan Perhitungan Manual, hal 12)

$$
S_{T}=\frac{M_{T}}{2 . Z}
$$

\section{Kode dan Standar Perpipaan}

Untuk merancang sistem pipa dengan benar, engineer harus memahami prilaku sistem pipa akibat pembebanan dan regulasi (kode standar design) yang mengatur perancangan sistem pipa. Prilaku sistem pipa ini antara digambarkan oleh parameterparameter fisis, seperti perpindahan, percepatan, tegangan, gaya, momen, dan besaran lainnya. Kegiatan perekayasaan untuk memperoleh prilaku sistem pipa ini dikenal sebagai analisis tegangan pipa atau dahulu disebut juga analisis flexibilitas. ${ }^{3}$

Kode dan Standar perpipaan adalah satu set persyaratan minmum yang harus digunakan pada setiap sistem perpipaan yang dibangun agar aman. Standar mencantumkan spesifikasi material yang diizinkan, rancang fabrikasi yang dapat diterima, serta persyaratan dan prosedur inspeksi ${ }^{4}$

Kode dan standar dikembangkan di negaranegara industri sebagai jawaban dari berbagai kecelakaan / kegagalan pada sistem pipa di pabrikpabrik yang tidak dirancang dengan aman. Karena itu tujuan utama dari kode dan standar adalah keamanan (safety). Analisis flexibilitas yang diharuskan oleh kode dan standar juga dimaksud untuk kepentingan keamanan. Pada saat ini ada beberapa buah kode standar dari komite B31 ini yang sering dipakai sebagai acuan di Indonesia sesuai kebutuhan bidang industri, yaitu:

- ASME/ANSI B31.1 untuk sistem perpipaan di industri pembangkit listrik;

- ASME/ANSI B31.3 untuk sistem perpipaan di industri proses dan petrokimia;

- ASME/ANSI B31.4 untuk pipa transport minyak dan zat cair lainnya;

- ASME/ANSI B31.5 untuk sistem perpipaan pendingin;

- ASME/ANSI B31.8 untuk pipa transport gas.

\section{Analisis ASME B31.3}

ASME B31.3 adalah jenis code yang digunakan dalam analisa tegangan pada system process piping (perpipaan daerah proses atau sekitar proses contohnya: turbin dan boiler), pada tugas akhir ini akan dibahas tentang analisis tegangan pipa pada sistem instalasi perpipaan pada proyek tangguh LNG dan sistem perpipaan LNG itu sendiri digolongkan pada code ini.

\section{Beban Ekspansi}

Beban Ekspansi adalah adalah stress yang terjadi akibat adanya perubahan temperatur, jika temperatur naik akan mengakibatkan pemuaian sedangkan jika suhu menurun maka akan terjadi pengkerutan. Pemuaian dan pengkerutan akan 
mengakibatkan kegagalan dan kebocorannpada sambungan, misalnya sambungan pada pompa, vessel, tank dan lain-lain

Stress yang diakibatkan oleh adanya ekspansi termal dan atau displacement (pergeseran) $S_{E}$ akan dihitung sebagai berikut:

$$
S_{E}=\sqrt{\left(S_{b}\right)^{2}+4\left(S_{t}\right)^{2}} \leq S_{A}
$$

Adapun batasan tegangan maksimum yang diizinkan material karena beban ekspansi adalah sebagai berikut:

$$
S_{A}=f\left(1,25 S_{\mathrm{c}}+0,25 S_{h}\right)
$$

Untuk menganalisis momen tekuk yang terjadi akibat perubahan temperatur maka terdapat teknik tersendiri yang dijadikan penulis sebagai acuan yaitu dengan menggunakan metode Grinnell, gambar isometrik yang merupakan gambar rangkaian pipa 3 dimensi yang diproyeksikan menjadi 2 dimensi dan dianalsis secara single plane, dimulai dengan menentukan lokasi titik berat (centeroid) atau pusat bidang dan momen inersia bidang, setelah itu dilakukan juga perhitungan gayagaya dan momen yang bekerja pada sistem tersebut, besar momen yang didapat akan menentukan besar tegangan ekspansi yang terjadi. Tegangan ekspansi yang terjadi akan dibandingkan dengan tegangan izin bahan, jika tegangan ekspansi yang terjadi lebih kecil dari tegangan izin bahan maka kontruksi sistem pipa tersebut aman.

Adapun langkah-langkah yang dilakukan dalam melakukan menghitung momen tekuk pada sistem perpipaan dengan teknik single plane antara lain:

\section{a. Menentukan titik berat dari setiap komponen pipa dalam satu rangkaian}

- Untuk pipa lurus, seperti terlihat pada Gambar

2.14 dibawah ini.

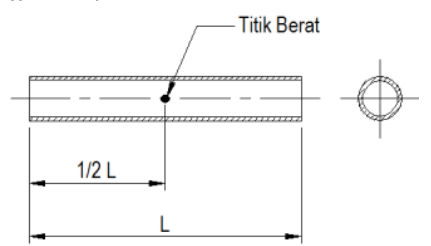

Gambar 2.14. Posisi titik berat untuk pipa lurus (Sumber: Veranika, R.M, Jurnal Desiminasi Teknologi, Vol. 3, No.1, hal. 92-100)

\section{b. Menenentuan titik pusat (centeroid) untuk satu bidang acuan}

Untuk pipa lurus, seperti terlihat pada Gambar 2.15 dibawah ini.

$$
=L \cdot X^{\prime}
$$

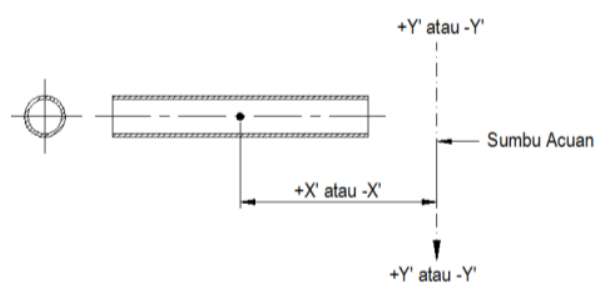

Gambar 2.15. Posisi titik pusat pada pipa lurus (Sumber: Veranika, R.M, Jurnal Desiminasi Teknologi, Vol. 3, No.1, hal. 92-100)

- Untuk pipa lurus yang tegak lurus dengan sumbu acuan, seperti terlihat pada Gambar 2.16 dibawah ini.

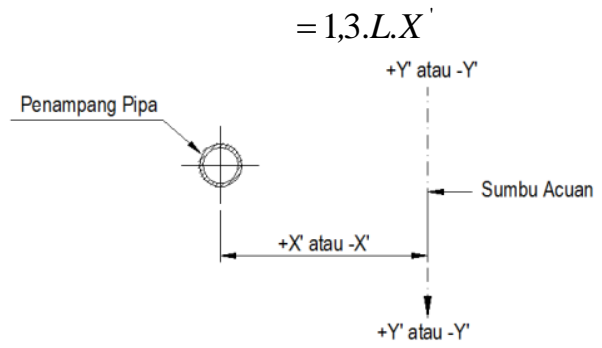

Gambar 2.16. Posisi titik pusat pada pipa yang tegak lurus sumbu acuan

(Sumber: Veranika, R.M, Jurnal Desiminasi Teknologi,Vol. 3, No.1, hal. 92-100)

\section{c. Menentukan momen inersia suatu bidang (jarak titik berat terhadap garis sumbu)}

- Untuk pipa lurus

$$
I x y=L . X . Y
$$

- Untuk pipa lurus yang tegak lurus dengan sumbu acuan

$$
I x y=1,3 \cdot L \cdot X . Y
$$

\section{d. Menentukan momen inersia pada satu sumbu}

- Untuk pipa lurus horizontal, seperti terlihat pada Gambar 2.17 dibawah ini.

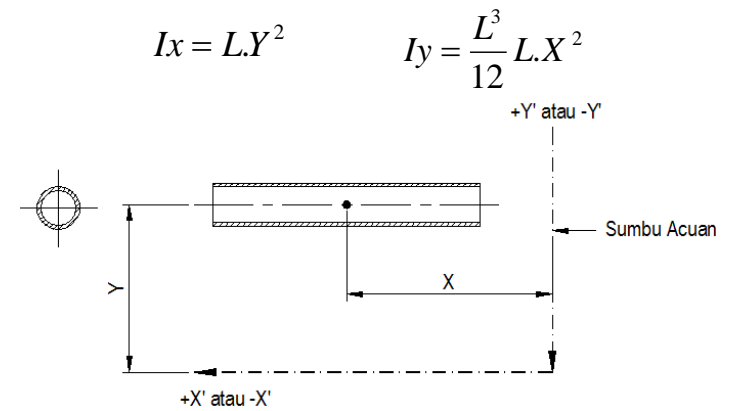

Gambar 2.17. Momen Inersia satu sumbu dengan orientasi pipa lurus Horizontal

(Sumber: Veranika, R.M, Jurnal Desiminasi Teknologi, Vol. 3, No.1, hal. 92-100)

- Untuk pipa lurus vertical, seperti terlihat pada Gambar 2.18 dibawah ini.

$$
I x=\frac{L^{3}}{12} L \cdot Y^{2} \quad I y=L \cdot X^{2}
$$




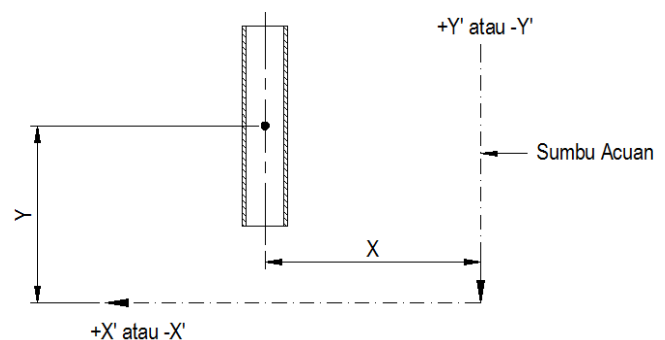

Gambar 2.18. Momen Inersia satu sumbu dengan orientasi pipa lurus Vertikal

(Sumber: Veranika, R.M, Jurnal Desiminasi Teknologi, Vol. 3, No.1, hal. 92-100)

- Untuk pipa lurus yang tegak lurus dengan bidang, seperti terlihat pada Gambar 2.19 dibawah ini.

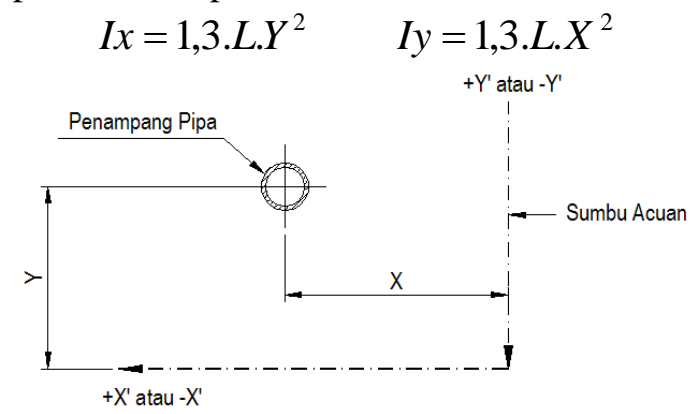

Gambar 2.19. Momen Inersia satu sumbu dengan orientasi pipa lurus yang tegak lurus dengan bidang acuan

(Sumber: Veranika, R.M, Jurnal Desiminasi Teknologi, Vol. 3, No.1, hal. 92-100)

\section{e. Menentukan gaya yang bekerja pada sumbu $\mathbf{X}, \mathbf{Y}, \mathbf{Z}$}

Setelah momen inersia bidang dan momen inersia pada satu sumbu telah diketahui, maka langkah selanjutnya adalah menentukan gaya-gaya yang bekerja pada sumbu $\mathrm{x}, \mathrm{y}$, dan $\mathrm{z}$ dengan cara sebagai berikut:

$$
\begin{aligned}
& F x . I x-F y . I x y-F z . I x z=\Delta x . E . I \\
& -F x . I x y+F y . I y-F z . I y z=\Delta y . E . I \\
& -F x . I x z-F y . I y z+F z . I z=\Delta z . E . I
\end{aligned}
$$

\section{Pengetahuan Perpipaan}

Pengetahuan perpipaan merupakan suatu sarana dan dasar dalam melakukan perhitungan, penganalisaan suatu instalasi perpipaan agai mencapai titik menuju kesempurnaan. Adapun halhal yang perlu diketahui dalam suatu sistem perpipaan antara lain:

\section{Jenis Pipa}

Secara umum jenis pipa dapat dikelompokkan menjadi dua bagian yaitu:

a. Jenis pipa tanpa sambungan (pembuatan pipa tanpa sambungan pengelasan).

b. Jenis pipa dengan sambungan (pembuatan pipa dengan pengelasan)

\section{Bahan-bahan Pipa Secara Umum}

Bahan-banan pipa yang dimaksudkan disini adalah struktur bahan baru pipa yang dapat dibagi secara umum sebagai berikut:

- Carbon steel, Carbon moly

- Galvanize, Ferro nikel

- Stainless steel, PVC (paralon)

- Chrome moly

\section{Komponen Perpipaan}

Komponen perpipaan harus dibuat berdasarkan spesifikasi, standara yang terdaftar dalam simbol dan kode yang telah dibuat atau dipilih sebelumnya. Komponen perpipaan yang dimaksud disini meliputi:

- Pipe (pipa), Flange (flens)

- Fitting (sambungan), Valve (katup)

- Bolting (baut), Gasket

\section{Macam Sambungan Perpipaan}

Sambungan perpipaan dapat dikelompokkan sebagai berikut:

a. Sambungan dengan menggunakan pengelasan.

b. Sambungan dengan menggunakan ulir.

\section{Tipe Sambungan Cabang}

Tipe sambungan cabang (branch connection) dapat dikelompokkan sebagai berikut:

a. Sambungan langsung (stub in).

b. Sambungan dengan menggunakan fitting (alat penyambung).

c. Sambungan dengan menggunakan flange (flens).

\section{Diameter, Ketebalan, Schedule}

Diameter nominal adalah diameter pipa yang dipilih untuk pemasangan ataupun perdagangan (commodity). Ketebalan dan schedule sangatlah berhubungan, hal ini karena ketebalan pipa tergantung dari pipa itu sendiri.

Schedule pipa ini dapat dikelompokkan sebagai berikut:

- Schedule: 5, 10, 20, 30, 40, 60, 80, 100, 120, 160.

- Schedule standard.

- Schedule extra strong (XS).

- Schedule double extra strong (XXS).

- Schedule special.

Perbedaan-perbedaan schedule ini dibuat guna:

a. Menahan internal pressure dari aliran.

b. Kekuatan dari material itu sendiri (strength of materials).

c. Mengatasi karat.

d. Mengatasi kegetasan pipa.

Berdasarkan kode ASME B31.3 mensyaratkan tebal minimum pipa didasarkan pada tekanan internal mencakup batas kelonggaran (allowance) untuk kekuatan mekanis tidak boleh kurang dari ketebalan yang dihitung dengan menggunakan persamaan dibawah ini. 


$$
t_{m}=\frac{P . d_{o}}{2\left(S E_{q}+P Y\right)}+A
$$

\section{Jarak Maksimum antar Tumpuan Pipa}

Jarak Allowable span sendiri sangat penting dalam upaya menjaga agar sistem perpipaan tidak mengalami tegangan yang berlebih (overstress) akibat berat pipa dan fluida didalamnya. Dengan perhitungan sederhana berdasarkan persyaratan tegangan menggunakan rumus dibawah ini.

$$
L=\sqrt{\frac{0,4 \cdot Z \cdot S_{h}}{W}}
$$

\section{METODE DAN PENGOLAHAN DATA Metode Penelitian}

Diagram alir dalam proses pelaksanaan penelitian yang akan dilakukan seperti terlihat pada Gambar 3.1dibawah ini.

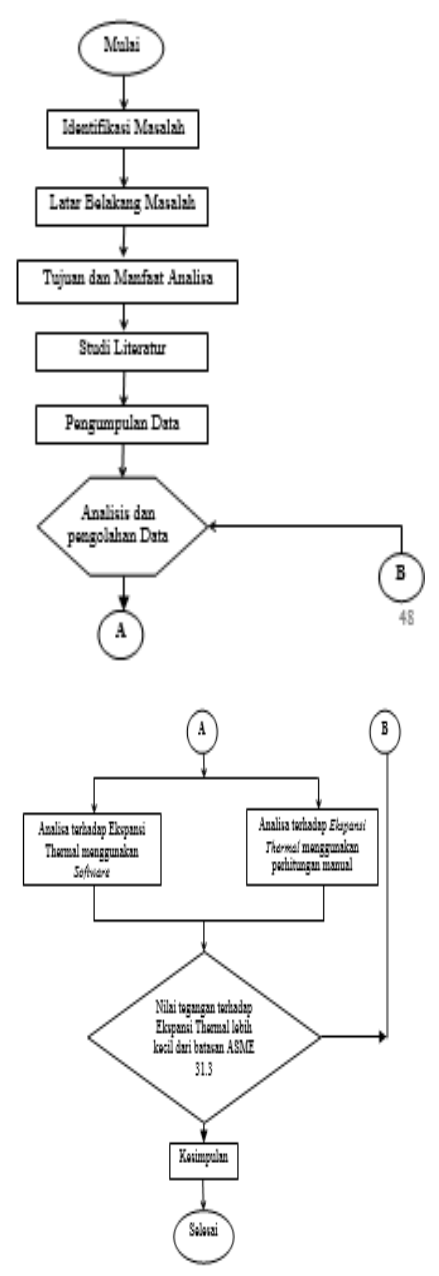

Gambar 3.1. Diagram Alir Metode Penelitian

\section{Prosedur Pengambilan Data}

Penulis mengadakan penelitian langsung pada perusahaan untuk memperoleh data atau bahan yang seobjektif mungkin. Adapun cara yang ditempuh adalah sebagai berikut.

a. Pengamatan

Yaitu mengadakan pengamatan langsung pada perusahaan yang menjadi objek penelitian dalam hubungan dan penyusunan tugas akhir ini.

b. Wawancara Berstruktur

Cara ini dilakukan dengan mengadakan wawancara langsung kepada pihak yang berwenang dalam perusahaan dengan melakukan tanya-jawab, yang selanjutnya hasilnya dianalisa sesuai dengan judul tugas akhir. Pertanyaan yang diajukan antara lain data tentang Piping \& Instrument Diagram, Plot Plan, Spesifikasi, dan data material.

\section{Proses Sistem Perpipaan}

Dalam perancangan suatu proyek memerlukan data-data pendukung untuk proses engineering yang memiliki keterkaitan satu dokumen dengan dokumen yang lainnya yang merupakan ringkasan yang telah disederhanakan dari berbagai spesifikasi dan ketentuan suatu proyek. Dokumen-dokumen tersebut adalah Proses Flow Diagram (PFD), Piping and Instrumentation Diagram (P\&ID), Piping Plan, Isometric Drawing, dan Pipe Support seperti terlihat pada Gambar 3.3, Gambar 3.5, Gambar 3.6, Gambar 3.7, Gambar 3.8 dibawah ini.

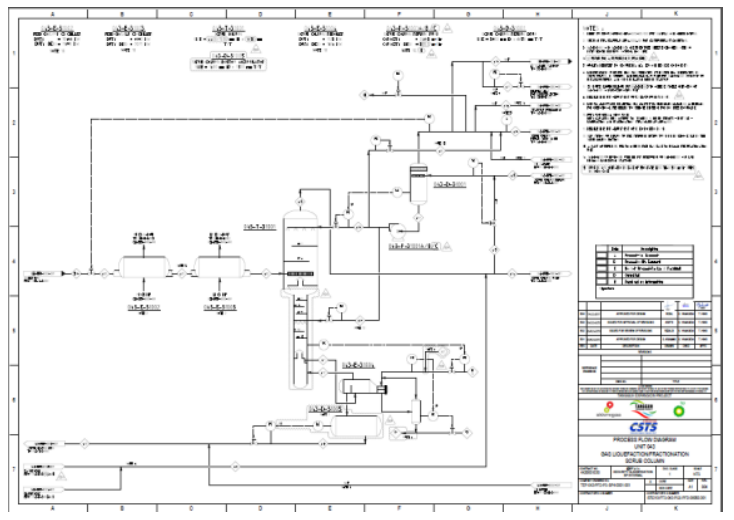

Gambar 3.2. Prosrs Flow Diagram (Sumber: PROYEK TANGGUH EXPANSION TRAIN 3) 


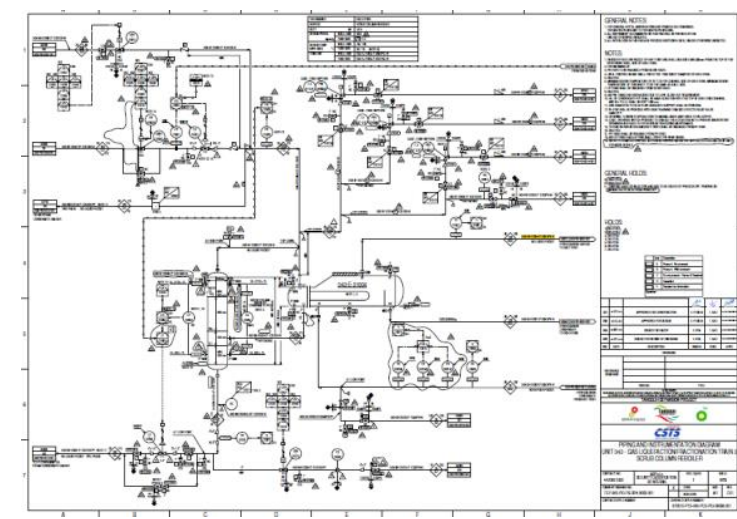

Gambar 3.3. Piping and Instrument Diagram (Sumber: PROYEK TANGGUH EXPANSION TRAIN 3)

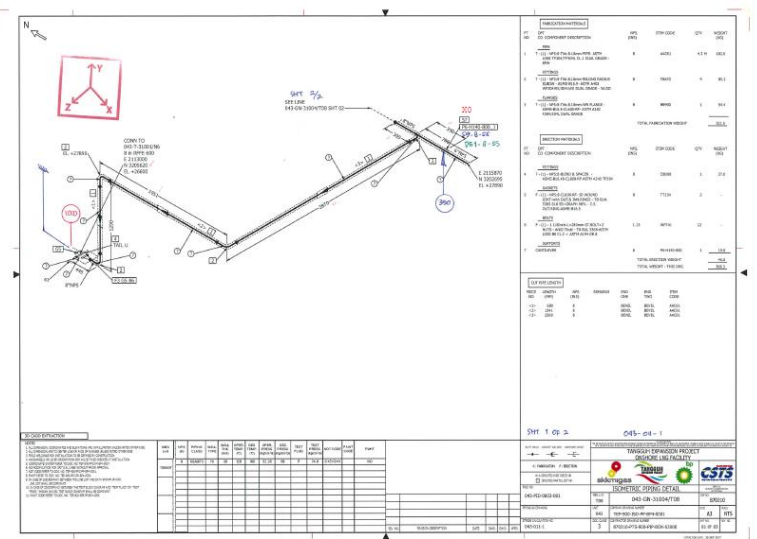

Gambar 3. 1. Isometric Drawing Line Number 043-GN$31004 / \mathrm{T} 081$ of 2

(Sumber: PROYEK TANGGUH EXPANSION TRAIN 3)

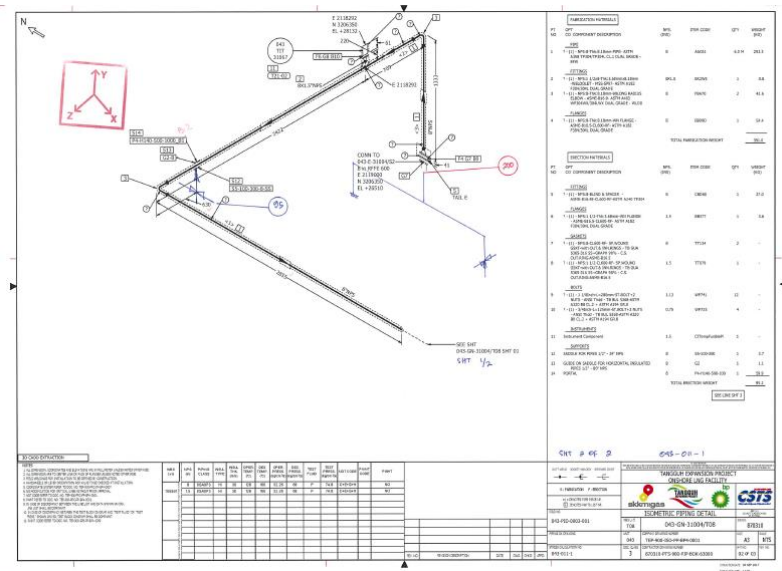

Gambar 3. 2. Isometric Drawing Line Number 043-GN31004/T08 1 of 2

(Sumber: PROYEK TANGGUH EXPANSION TRAIN 3)

\section{Alat yang Digunakan}

1. Meteran Laser

Berfungsi untuk mengukur jarak dengan jangkauan yang jauh dan ketinggian.

2. Meteran Manual

Berfungsi untuk mengukur dengan area yang bisa di jangkau oleh tangan atau area jarak dekat.

3. Kamera Digital
Berfungsi untuk mengambil gambar pada area yang akan di ganti.

4. Komputer atau Laptop

Berfungsi untuk membuat gambar dengan sofware autoCAD dan SP3D menjadi gambar kerja sesuai yang di inginkan dengan referensi dari hasil survey yang di lakukan di lapangan.

\section{Spesifikasi Data}

Pengumpulan data yang dilakukan di Proyek X, diperoleh data-data sistem perpipaan pada area cluster, Adapun parameter-parameter yang menjadi dasar perhitungan manual dan data masukan (input) kedalam program CAESAR II yang akan diproses adalah berikut:

1) Pipe data Class 6SA0PA3

- Design code : ASME B31.3

- Material : A358 304L

- Wall thickness $\quad: 8.1788 \mathrm{~mm}$

- Inside Diameter (di) : $198.48 \mathrm{~mm}$

- Outside Diameter (do) : $219.1 \mathrm{~mm}$

- Operating pressure (P2) $\quad: 52.6 \mathrm{~kg} / \mathrm{cm}^{2}$

- Operating temperature (T2) : $127.45{ }^{\circ} \mathrm{C}$

- Design pressure (P1)

: $68 \mathrm{~kg} / \mathrm{cm}^{2}$

- Design temperature (T1)

- Hydrotest pressure

: $160{ }^{\circ} \mathrm{C}$

Corrosion Allowance (A)

: $74.8 \mathrm{~kg} / \mathrm{cm}^{2}$

- Fluid

: $0 \mathrm{~mm}$

- Fluid density

- Pipe density

: Two Phase

: $77 \mathrm{~kg} / \mathrm{m}^{3}$

- Insulation Thickness : $30 \mathrm{~mm}$

- Modulus of Elasticity (E): $1.9463 \times 10^{6}-\mathrm{kg} / \mathrm{cm}^{2}=$ $19643 \mathrm{~kg} / \mathrm{mm}^{2}$

- Mill Tolerance: $12.5 \%$ (database program)

- Weld Joint Factor (Ej) :

1 (untuk pipa tanpa sambungan)

- Coefficient Y : 0,4(temperatur dibawah 9000F dan dapat dilihat pada Tabel 104.1.2(A) Value of Y)

- Max. Yield strength (Sy): $1757674.323036 \mathrm{~kg} / \mathrm{cm}^{2}$

- Max. Allowable stress (S): $1541197.24881 \mathrm{~kg} / \mathrm{cm}^{2}$

- Max. Tensile stress (Sh): $1541197.24881 \mathrm{~kg} / \mathrm{cm}^{2}$

- Max. Allowable stress in material (SE) :

$1541197.24881 \mathrm{~kg} / \mathrm{cm}^{2}$

Tabel 3.2. Pipe material spesification Class 6SA0PA3

\begin{tabular}{|c|l|c|c|}
\hline No & \multicolumn{1}{|c|}{ MATERIAL DESCRIPTION } & \multicolumn{2}{|c|}{ WEIGHT } \\
\hline 1 & $\begin{array}{l}\text { PIPE, 8", ASTM A312 TP304/TP304L DUAL GRADE-SMLS } \\
\text { SCH 40S }\end{array}$ & 43 & $\mathrm{Kg} / \mathrm{m}$ \\
\hline 2 & $\begin{array}{l}\text { ELBOW 90 LONG RADIUS, 8", ASTMA403 } \\
\text { WP304WX/304LWX DUAL GRADE-WLDD, SCH-40S, } \\
\text { ASME B16.9 }\end{array}$ & 19.91 & $\mathrm{~kg}$ \\
\hline 3 & $\begin{array}{l}\text { WNFLANGE-ASME B16.5, 8", 600\#-RF, ASTM A182 } \\
\text { F304/304L DUAL GRADE (include bolt \& nuts) }\end{array}$ & 77.04 & $\mathrm{~kg}$ \\
\hline
\end{tabular}

\section{ANALISIS DAN PEMBAHASAN \\ Perhitungan dan simulasi \\ Perhitungan Ketebalan Minimum Dinding Pipa}


Setiap pipa memiliki ketebalan yang berbeda-beda sesuai dengan keadaan sistem perpipaan itu.

$$
\begin{aligned}
t_{m} & =\frac{P D_{0}}{2(S E+P Y)}+A \\
& \left.=\frac{68 \mathrm{~kg} / \mathrm{cm}^{2} \times 21,9 \mathrm{~cm}}{2\left[\left(1541197.24881 \mathrm{~kg} / \mathrm{cm}^{2} \times 1,0\right)+\left(68 \mathrm{~kg} / \mathrm{cm}^{2} \times 0,4\right)\right.}\right]+0 \mathrm{~cm} \\
& =\frac{1489,2 \mathrm{~kg} / \mathrm{cm}}{3082448,896 \mathrm{~kg} / \mathrm{cm}^{2}}+0 \mathrm{~cm} \\
& =0,0005 \mathrm{~cm}=0,005 \mathrm{~mm}
\end{aligned}
$$

\section{Perhitungan Jarak Maksimum Penyangga Pipa}

Ketepatan pemilihan dan perhitungan jarak penyangga menjadi factor penentu dalam keberhasilan analisis fleksibilitas.

$$
\begin{aligned}
W=W_{p}+W_{c} & \Rightarrow W_{p}=\pi / 4\left(d_{o}{ }^{2}-d_{i}{ }^{2}\right) \times \text { density of pipe } \\
& \Rightarrow W_{c}=\pi / 4\left(d_{i}{ }^{2}\right) \times \text { density of fluida }
\end{aligned}
$$

Penyelesaian :

- Perhitungan berat pipa per satuan panjang

$$
\begin{aligned}
W_{p} & =\pi / 4\left(d_{o}{ }^{2}-d_{i}^{2}\right) \times \text { density of pipe } \\
& =3,14 / 4\left(0,219^{2}-0,198^{2}\right)\left(8027,1997 \mathrm{~kg} / \mathrm{m}^{3}\right) \\
& =0,785\left(0,008757 \mathrm{~m}^{2}\right)\left(8027,1997 \mathrm{~kg} / \mathrm{m}^{3}\right) \\
& =55,28 \mathrm{~kg} / \mathrm{m} \\
W_{c} & =\pi / 4\left(d_{i}^{2}\right) \times \text { density of fluida } \\
& =3,14 / 4\left(0,198^{2}\right)\left(77 \mathrm{~kg} / \mathrm{m}^{3}\right) \\
& =0,785\left(0,039204 \mathrm{~mm}^{2}\right)\left(77 \mathrm{~kg} / \mathrm{m}^{3}\right) \\
& =2,4 \mathrm{~kg} / \mathrm{m}
\end{aligned}
$$

$$
\mathrm{W}=\mathrm{Wp}+\mathrm{Wc}=55,28+2,4=57,68 \mathrm{~kg} / \mathrm{m}
$$

- Perhitungan modulus penampang pipa (Z)

$$
\begin{aligned}
Z & =\frac{\pi\left(d_{o}{ }^{4}-d_{i}{ }^{4}\right)}{32 d_{o}} \\
& =\frac{3,14\left[(219 \mathrm{~mm})^{4}-(198 \mathrm{~mm})^{4}\right]}{32(219 \mathrm{~mm})} \\
& =\frac{3,14(2300257521-1536953616) \mathrm{mm}^{4}}{7008 \mathrm{~mm}} \\
& =\frac{2396774262 \mathrm{~mm}^{4}}{7008 \mathrm{~mm}^{3}} \\
& =342005,45 \mathrm{~mm}^{3}
\end{aligned}
$$

- Perhitungan Momen Inersia Pipa

$$
\begin{aligned}
& I=\frac{\pi\left(d_{o}{ }^{4}-d_{i}{ }^{4}\right)}{64} \\
& =\frac{3,14\left(219^{4}-198^{4}\right)}{64} \\
& =\frac{3,14(2300257521-1536953616)}{64} \\
& =37449597,84 \mathrm{~mm}^{4}
\end{aligned}
$$

- Perhitungan Jarak Maksimum Penyangga Pipa

$$
\begin{aligned}
& L=\sqrt{\frac{0,4 \cdot Z \cdot S_{h}}{W}} \\
& =\sqrt{\frac{0,4\left(342005,45 \mathrm{~mm}^{3}\right)\left(1541197,24 \mathrm{~kg} / \mathrm{cm}^{2}\right)}{57,68 \mathrm{~kg} / \mathrm{m}}} \\
& =\sqrt{\frac{0,4\left(342005,45 \mathrm{~mm}^{3}\right)\left(1541197,24 \mathrm{~kg} / \mathrm{cm}^{2} \times 10\right)}{(57,68 \mathrm{~kg} / \mathrm{mm})}} \\
& =\sqrt{\frac{0,4\left(342005,45 \mathrm{~mm}^{3}\right)\left(154119,724 \mathrm{~kg} / \mathrm{mm}^{2}\right)}{(57,68 \mathrm{~kg} / \mathrm{mm})}} \\
& =19118 \mathrm{~mm}
\end{aligned}
$$

\section{Perhitungan Tegangan Aksial $\left(S_{a x}\right)$}

Untuk menghitung tegangan akibat gaya yang searah dengan sumbu pipa.

$$
\begin{aligned}
A_{i} & =\frac{\pi}{4} d_{i}^{2} \\
& =\frac{3,14}{4}(198)^{2} \\
& =3077514 \mathrm{~mm}^{2}=307,7514 \mathrm{~cm}^{2} \\
F_{a x} & =P . A_{i} \\
& =68 \mathrm{~kg} / \mathrm{cm}^{2} \times 307,7514 \mathrm{~cm}^{2} \\
& =20927,09 \mathrm{~kg} \\
A_{m} & =\frac{\pi}{4}\left(d_{o}{ }^{2}-d_{i}^{2}\right) \\
& =\frac{3,14}{4}\left[(219 m m)^{2}-(198 m m)^{2}\right] \\
& =0,785(47961-39204) \\
& =6874,245 \mathrm{~mm}^{2}=68,74245 \mathrm{~cm}^{2} \\
S_{a x} & =\frac{F_{a x}}{A_{m}}=\frac{20927,09 \mathrm{~kg}}{68,74245 \mathrm{~cm}^{2}}=304,427 \mathrm{~kg} / \mathrm{cm}^{2}
\end{aligned}
$$

\section{Perhitungan Tegangan Tekan (Sp)}

Untuk menghitung tegangan akibat tekanan dalam pipa. 


$$
\begin{aligned}
S_{p} & =\frac{P \cdot d_{o}}{4 t} \\
& =\frac{68 \mathrm{~kg} / \mathrm{cm}^{2} \times 21,9 \mathrm{~cm}}{4(0,81788 \mathrm{~cm})} \\
& =\frac{14892 \mathrm{~kg} / \mathrm{cm}^{2} \cdot \mathrm{cm}}{3.27152 \mathrm{~cm}} \\
& =4552 \mathrm{~kg} / \mathrm{cm}^{2}
\end{aligned}
$$

\section{Perhitungan Tegangan Tangensial $\left(S_{H}\right)$}

$$
\begin{aligned}
S_{H} & =\frac{P . d_{o}}{2 t} \\
& =\frac{68 \mathrm{~kg} / \mathrm{cm}^{2} \times 21,9 \mathrm{~cm}}{2(0,81788 \mathrm{~cm})} \\
& =\frac{14892 \mathrm{~kg} / \mathrm{cm}^{2} \cdot \mathrm{cm}}{1,63576 \mathrm{~cm}} \\
& =9104 \mathrm{~kg} / \mathrm{cm}^{2}
\end{aligned}
$$

\section{Perhitungan Tegangan Radial $\left(S_{R}\right)$}

$$
\begin{aligned}
S_{R} & =\frac{P . r_{i}^{2}}{r_{o}^{2}-r_{i}^{2}}\left(1-\frac{r_{o}^{2}}{r^{2}}\right) \\
& =\frac{68 \mathrm{~kg} / \mathrm{cm}^{2} \times(9,9 \mathrm{~cm})^{2}}{\left((10,95 \mathrm{~cm})^{2}-(9,9 \mathrm{~cm})^{2}\right)}\left(1-\frac{(10,95 \mathrm{~cm})^{2}}{(9,9 \mathrm{~cm})^{2}}\right) \\
& =\frac{68 \mathrm{~kg} / \mathrm{cm}^{2} \times 98,01 \mathrm{~cm}^{2}}{21,89 \mathrm{~cm}^{2}}(-0,2) \\
& =\frac{66646,68 \mathrm{~kg} / \mathrm{cm}^{2} \cdot \mathrm{cm}^{2}}{21,98 \mathrm{~cm}^{2}}(-0,2) \\
& =-60,64 \mathrm{~kg} / \mathrm{cm}^{2}
\end{aligned}
$$

\begin{tabular}{|c|c|c|c|c|c|}
\hline Node & $\mathrm{L}(\mathrm{mm})$ & $\mathbf{X}^{\prime}(\mathrm{mm})$ & L. $\mathbf{X}^{\prime}\left(\mathrm{mm}^{2}\right)$ & $Y^{\prime}(\mathrm{mm})$ & L.Y' $\left(\mathrm{mm}^{2}\right)$ \\
\hline $1000-40$ & 445.00 & 222.50 & 99012.50 & 0.00 & 0.00 \\
\hline $40-50$ & 1290.00 & 0.00 & 0.00 & -645.00 & -832050.00 \\
\hline $50-60$ & 1951.00 & 1420.50 & 2771395.50 & 0.00 & 0.00 \\
\hline $60-70$ & 3731.00 & 0.00 & 0.00 & 0.00 & 0.00 \\
\hline $70-90$ & 3160.00 & 3976.00 & 12564160.00 & 0.00 & 0.00 \\
\hline $90-110$ & 4889.30 & 0.00 & 0.00 & 0.00 & 0.00 \\
\hline $110-200$ & 1333.00 & 0.00 & 0.00 & -1956.50 & -2608014.50 \\
\hline Total & 16799.30 & & 15434568.00 & & -3440064.50 \\
\hline
\end{tabular}

\section{Perhitungan Tegangan Pipa Akibat Beban} Ekspansi dengan Perhitungan Manual

Untuk mendapatkan tegangan tekuk dan tegangan torsi pada sistem peripaan penulis menggunakan metode Grinnell dengan membagi gambar sistem perpipaan dari bentuk 3 dimensi menjadi gambar proyeksi 2 dimensi dengan sumbu $\mathrm{X}-\mathrm{Y}, \mathrm{X}-\mathrm{Z}, \mathrm{Y}-\mathrm{Z}$. pembagian tersebut dinamakan single plane system.

\section{A. Perhitungan Titik Pusat (centeroid) pada Bidang X-Y}

Tabel 4.1. Penentuan nilai centeroid bidang X-Y

Maka posisi titik pusat dari sumbu X-Y adalah:

$$
\begin{aligned}
& \underline{X}=\frac{\sum L X^{i}}{\sum L}=\frac{15434568 \mathrm{~mm}^{2}}{16799,30 \mathrm{~mm}}=918,76 \mathrm{~mm}\left(\text { ke kanan dari sumbuY }{ }^{\mathrm{i}}\right) \\
& \underline{Y}=\frac{\sum L Y^{i}}{\sum L}=\frac{-3440064,50 \mathrm{~mm}^{2}}{16799,30 \mathrm{~mm}}=-204,77 \mathrm{~mm}\left(\text { ke bawah dari sumbuX }{ }^{\mathrm{i}}\right)
\end{aligned}
$$

\begin{tabular}{|c|c|c|c|c|c|}
\hline Node & $\mathrm{L}(\mathrm{mm})$ & $\mathrm{X}(\mathrm{mm})$ & $\mathrm{Y}(\mathrm{mm})$ & Ix & Hasil $\left(\mathrm{mm}^{3}\right)$ \\
\hline $1000-40$ & 445.00 & 1141.26 & -204.77 & $L Y^{2}$ & 18659964.39 \\
\hline $40-50$ & 1290.00 & 918.76 & -849.77 & $L^{3} / 12+L X^{2}$ & 1267811555.49 \\
\hline $50-60$ & 1951.00 & 2339.26 & -204.77 & $\mathrm{LY}^{2}$ & 81810315.77 \\
\hline $60-70$ & 3731.00 & 918.76 & -204.77 & $L^{3} / 12+L X^{2}$ & 7477501330.28 \\
\hline $70-90$ & 3160.00 & 4894.76 & -204.77 & $L Y^{2}$ & 132506713.39 \\
\hline $90-110$ & 4889.30 & 918.76 & -204.77 & $L^{3} / 12+L X^{2}$ & 13867175409.23 \\
\hline $110-200$ & 1333.00 & 918.76 & -2161.27 & $L^{3 / 1} / 12+L X^{2}$ & 1322600918.75 \\
\hline Total & & & & & 24168066207.29 \\
\hline
\end{tabular}

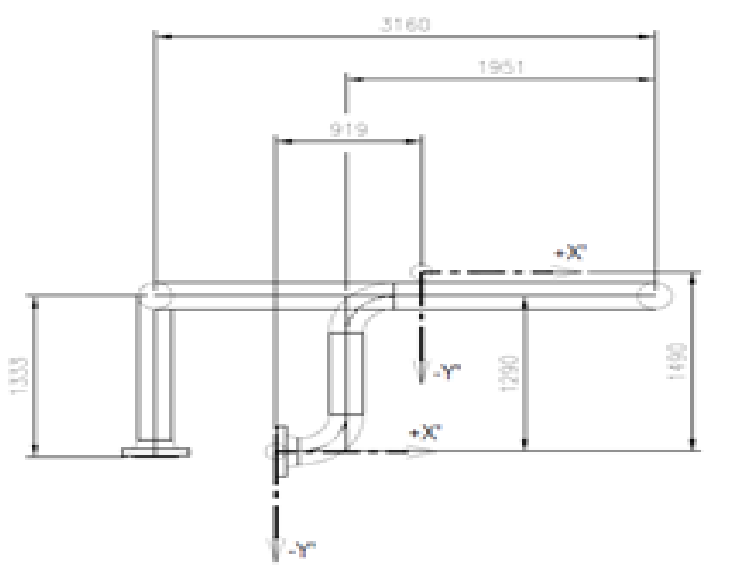

\section{Proyeksi Bidang $X-Y$}

Gambar 4.2. Posisi centeroid sistem perpipaan pada bidang $\mathrm{X}-\mathrm{Y}$

(Sumber : Program AutoCAD 2010)

\section{a. Menentukan Momen Inersia Bidang X-Y (Ixy)}

Tabel 4.2. Nilai Momen Inersia bidang X-Y

\begin{tabular}{|c|r|r|}
\hline Node & Ixy & \multicolumn{1}{c|}{ Hasil $\left(\mathrm{mm}^{3}\right)$} \\
\hline $1000-40$ & $445 \times(1141.26) \times(-204.77)$ & -103997041.27 \\
\hline $40-50$ & $1290 \times(918.76) \times(-849.77)$ & -1007155626.69 \\
\hline $50-60$ & $1951 \times(2339.26) \times(-204.77)$ & -934569579.54 \\
\hline $60-70$ & $3731 \times(918.76) \times(-204.77)$ & -701946384.61 \\
\hline $70-90$ & $3160 \times(4894.76) \times(-204.77)$ & -3167335821.38 \\
\hline $90-110$ & $4889.30 \times(918.76) \times(-204.77)$ & -919867718.64 \\
\hline $110-200$ & $1333 \times(918.76) \times(-2161.27)$ & -2646935304.90 \\
\hline Total & & -9481807477.03 \\
\hline
\end{tabular}

\section{b. Menentukan Momen Inersia Bidang X-Y Pada Sumbu X $(I x)$}

Tabel 4.3. Nilai Momen Inersia bidang X-Y pada sumbu X

\section{c. Menentukan Momen Inersia Bidang X-Y Pada Sumbu Y (Iy)}

Tabel 4.4. Nilai Momen Inersia bidang X-Y pada sumbu Y 


\begin{tabular}{|c|c|c|c|c|c|}
\hline Node & $\mathrm{L}(\mathrm{mm})$ & $\mathrm{X}(\mathrm{mm})$ & $\mathrm{Y}(\mathrm{mm})$ & Iy & Hasil $\left(\mathrm{mm}^{3}\right)$ \\
\hline $1000-40$ & 445.00 & 1141.26 & -204.77 & $L^{3} / 12+L Y^{2}$ & 26003391.47 \\
\hline 40.50 & 1290.00 & 918.76 & -849.77 & $L X^{2}$ & 1088920805.49 \\
\hline 50.60 & 1951.00 & 2339.26 & -204.77 & $L^{3} / 12+L Y^{2}$ & 700667678.35 \\
\hline 60.70 & 3731.00 & 918.76 & -204.77 & $L^{3} / 12+L Y^{2}$ & 4484522414.23 \\
\hline $70-90$ & 3160.00 & 4894.76 & .204 .77 & $L^{3} / 12+L Y^{2}$ & 2762048046.73 \\
\hline $90-110$ & 4889.30 & 918.76 & -204.77 & $L^{3} / 12+L Y^{2}$ & 9945017324.47 \\
\hline $110-200$ & 1333.00 & 918.76 & -2161.27 & $L X^{2}$ & 1125218165.67 \\
\hline Total & & & & & 20132397826.40 \\
\hline
\end{tabular}

\section{Perhitungan Titik Pusat (centeroid) pada Bidang} $\mathbf{X}-\mathbf{Z}$

Tabel 4.5. Nilai Momen Inersia bidang X-Y pada sumbu Y

\begin{tabular}{|c|c|c|c|c|c|}
\hline Node & $\mathrm{L}(\mathrm{mm})$ & $\mathrm{X}^{\prime}(\mathrm{mm})$ & L. $\mathbf{X}^{\prime}\left(\mathrm{mm}^{2}\right)$ & $Z^{\prime}(\mathrm{mm})$ & L. $Z^{\prime}\left(\mathrm{mm}^{2}\right)$ \\
\hline $1000-40$ & 445.00 & 222.50 & 99012.50 & 0.00 & 0.00 \\
\hline $40-50$ & 1677.00 & 0.00 & 0.00 & 0.00 & 0.00 \\
\hline $50-60$ & 1951.00 & 1420.50 & 2771395.50 & 0.00 & 0.00 \\
\hline $60-70$ & 2870.00 & 0.00 & 0.00 & 1435.00 & 4118450.00 \\
\hline $70-90$ & 3160.00 & 3976.00 & 12564160.00 & 0.00 & 0.00 \\
\hline $90-110$ & 3131.00 & 0.00 & 0.00 & 4750.50 & 14873815.50 \\
\hline $110-200$ & 1732.90 & 0.00 & 0.00 & 0.00 & 0.00 \\
\hline Total & 14966.90 & & 15434568.00 & & 18992265.50 \\
\hline
\end{tabular}

Maka posisi titik pusat dari sumbu X-Z adalah:

$\underline{X}=\frac{\sum L X^{i}}{\sum L}=\frac{15434568 \mathrm{~mm}^{2}}{14966,90 \mathrm{~mm}}=1031,25 \mathrm{~mm}$ (ke kanan dari sumbu $\left.Z^{i}\right)$

$\underline{Z}=\frac{\sum L Z^{i}}{\sum L}=\frac{18992265,50 \mathrm{~mm}^{2}}{14966,90 \mathrm{~mm}}=1268,95 \mathrm{~mm}\left(\right.$ ke bawah dari sumbu $\mathrm{X}^{\mathrm{i}}$ )

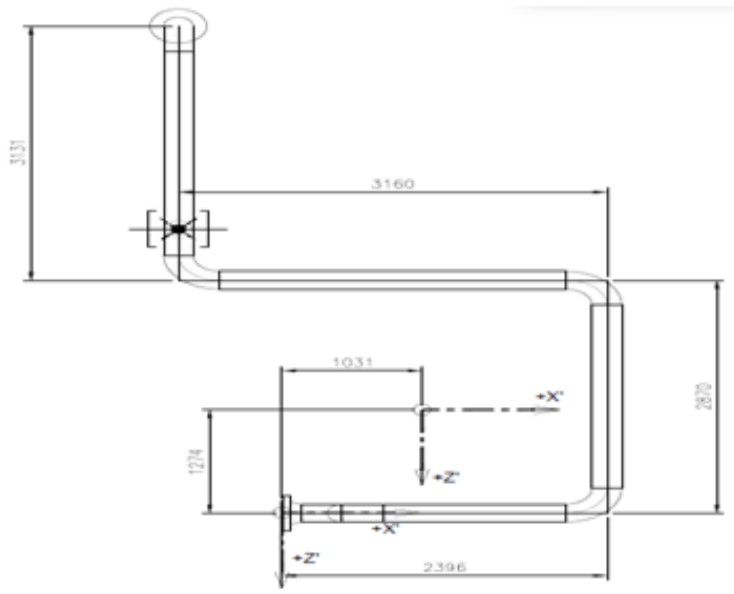

Proyeksi Bidang $X-Z$

Gambar 4.4. Posisi centeroid sistem perpipaan pada bidang $\mathrm{X}-\mathrm{Z}$

(Sumber: Program AutoCAD 2010)

a. Menentukan Momen Inersia Bidang X-Z (Ixz)

Tabel 4.6. Nilai Momen Inersia bidang X-Z

\begin{tabular}{|c|r|r|}
\hline Node & Ixz & \multicolumn{1}{|c|}{ Hasil $\left(\mathrm{mm}^{3}\right)$} \\
\hline $1000-40$ & $445 \times(1253.75) \times(1268.95)$ & \multicolumn{1}{|c|}{707969862.46} \\
\hline $40-50$ & $1677 \times(1031.25) \times(1268.95)$ & 2194525339.91 \\
\hline $50-60$ & $1951 \times(2451.75) \times(1268.95)$ & 6069847858.47 \\
\hline $60-70$ & $2870 \times(1031.25) \times(2703.95)$ & 8002825831.11 \\
\hline $70-90$ & $3160 \times(5007.25) \times(1268.95)$ & 20078487644.86 \\
\hline $90-110$ & $3131 \times(1031.25) \times(6019.45)$ & 19435807367.86 \\
\hline $110-200$ & $1732.90 \times(1031.25) \times$ & 19435807367.86 \\
\hline Total & $(6019.45)$ & 75925271272.51 \\
\hline
\end{tabular}

b. Menentukan Momen Inersia Bidang X-Z Pada Sumbu X $(I x)$

Tabel 4.7. Nilai Momen Inersia bidang X-Z pada sumbu X

\begin{tabular}{|c|c|c|c|c|c|}
\hline Node & $\mathrm{L}(\mathrm{cm})$ & $\mathrm{X}(\mathrm{mm})$ & $\mathrm{Z}(\mathrm{mm})$ & Ix & Hasil $\left(\mathrm{mm}^{3}\right)$ \\
\hline $1000-40$ & 445.00 & 1253.75 & 1268.95 & $L Z^{2}$ & 716555514.61 \\
\hline $40-50$ & 1677.00 & 1031.25 & 1268.95 & $L^{3} / 12+L X^{2}$ & 2176462167.06 \\
\hline $50-60$ & 1951.00 & 2451.75 & 1268.95 & $L Z^{2}$ & 3141572604.49 \\
\hline $60-70$ & 2870.00 & 1031.25 & 2703.95 & $L^{3} / 12+L X^{2}$ & 5022150815.49 \\
\hline $70-90$ & 3160.00 & 5007.25 & 1268.95 & $L Z^{2}$ & 5088349272.27 \\
\hline $90-110$ & 3131.00 & 1031.25 & 6019.45 & $L^{3} / 12+L X^{2}$ & 5887532659.63 \\
\hline $110-200$ & 1732.90 & 1031.25 & 6019.45 & $L^{3} / 12+L X^{2}$ & 2276537070.81 \\
\hline Total & & & & & 24309160104.37 \\
\hline
\end{tabular}

c. Menentukan Momen Inersia Bidang X-Z Pada Sumbu Z (Iz)

Tabel 4.8. Nilai Momen Inersia bidang X-Z pada sumbu Z

\begin{tabular}{|c|c|c|c|c|c|}
\hline Node & $\mathrm{L}(\mathrm{mm})$ & $\mathrm{X}(\mathrm{mm})$ & $\mathrm{Z}(\mathrm{mm})$ & Iz & Hasil $\left(\mathrm{mm}^{3}\right)$ \\
\hline $1000-40$ & 445.00 & 1253.75 & 1268.95 & $L^{3} / 12+L Z^{2}$ & 723898941.69 \\
\hline $40-50$ & 1677.00 & 1031.25 & 1268.95 & $L^{3} / 12+L Z^{2}$ & 3093390613.70 \\
\hline $50-60$ & 1951.00 & 2451.75 & 1268.95 & $L^{3} / 12+L Z^{2}$ & 3760429967.07 \\
\hline $60-70$ & 2870.00 & 1031.25 & 2703.95 & $L X^{2}$ & 3052158898.82 \\
\hline $70-90$ & 3160.00 & 5007.25 & 1268.95 & $L^{3} / 12+L Z^{2}$ & 7717890605.60 \\
\hline $90-110$ & 3131.00 & 1031.25 & 6019.45 & $L X^{2}$ & 3329724568.72 \\
\hline $110-200$ & 1732.90 & 1031.25 & 6019.45 & $L^{3} / 12+L Z^{2}$ & 63223189063.50 \\
\hline Total & & & & & 84900682659.11 \\
\hline
\end{tabular}

\section{Perhitungan Titik Pusat (centeroid) pada Bidang} Z-Y

Tabel 4.9. Penentuan nilai centeroid bidang Z-Y

\begin{tabular}{|c|r|r|r|r|r|}
\hline Node & L (mm) & \multicolumn{1}{c|}{$Z^{\prime}(\mathrm{mm})$} & \multicolumn{1}{c|}{ L.Z' $\left(\mathrm{mm}^{2}\right)$} & \multicolumn{1}{c|}{$\mathrm{Y}^{\prime}(\mathrm{mm})$} & \multicolumn{1}{c|}{ L.Y' $\left(\mathrm{mm}^{2}\right)$} \\
\hline $1000-40$ & 578.50 & 0.00 & 0.00 & 0.00 & 0.00 \\
\hline $40-50$ & 1290.00 & 0.00 & 0.00 & -645.00 & -832050.00 \\
\hline $50-60$ & 2536.30 & 0.00 & 0.00 & 0.00 & 0.00 \\
\hline $60-70$ & 2870.00 & 1435.00 & 4118450.00 & 0.00 & 0.00 \\
\hline $70-90$ & 4108.00 & 0.00 & 0.00 & 0.00 & 0.00 \\
\hline $90-110$ & 3761.00 & 4750.50 & 17866630.50 & 0.00 & 0.00 \\
\hline $110-200$ & 1333.00 & 0.00 & 0.00 & -1956.50 & -2608014.50 \\
\hline Total & 16476.80 & & 21985080.50 & & -3440064.50 \\
\hline
\end{tabular}

Maka posisi titik pusat dari sumbu Z-Y adalah:

$$
\begin{aligned}
& \underline{Z}=\frac{\sum L Z^{i}}{\sum L}=\frac{21985000,50 \mathrm{~mm}^{2}}{16476,80 \mathrm{~mm}}=1334,31 \mathrm{~mm}\left(\text { ke bawah dari sumbu } Y^{\mathrm{i}}\right) \\
& \underline{Y}=\frac{\sum L Y^{i}}{\sum L}=\frac{-3440064,50 \mathrm{~mm}^{2}}{16476,80 \mathrm{~mm}}=-208,78 \mathrm{~mm}\left(\text { ke kanan dari sumbu } Z^{i}\right)
\end{aligned}
$$




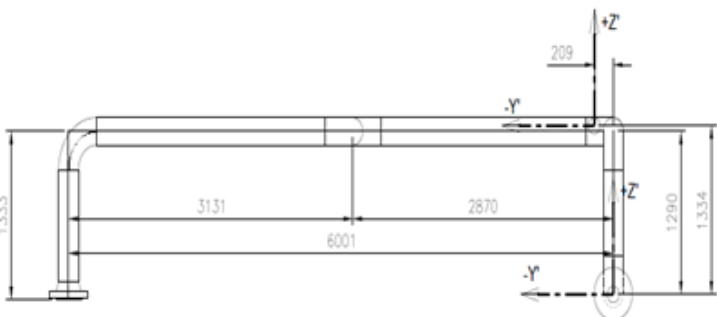

\section{Proyeksi Bidang Z-Y}

Gambar 4.6. Posisi centeroid sistem perpipaan pada bidang Z-Y

(Sumber : Program AutoCAD 2010)

a. Menentukan Momen Inersia Bidang Z-Y (Izy)

Tabel 4.10. Nilai Momen Inersia bidang Z-Y

\begin{tabular}{|c|r|r|}
\hline Node & \multicolumn{1}{|c|}{ Iyz } & \multicolumn{1}{c|}{ Hasil $\left(\mathrm{mm}^{3}\right)$} \\
\hline $1000-40$ & $578.50 \times(1334.31) \times(-208.78)$ & -161158148.28 \\
\hline $40-50$ & $1290 \times(1334.31) \times(-853.78)$ & -1469576019.78 \\
\hline $50-60$ & $2536.30 \times(1334.31) \times(-208.78)$ & -706560780.44 \\
\hline $60-70$ & $2870 \times(2769.31) \times(-208.78)$ & -1659382244.51 \\
\hline $70-90$ & $4108 \times(1334.31) \times(-208.78)$ & -1144403929.37 \\
\hline $90-110$ & $3761 \times(6084.81) \times(-208.78)$ & -4777973431.99 \\
\hline $110-200$ & $1333 \times(1334.31) \times(-2165.28)$ & -3851233661.36 \\
\hline Total & & -13770288215.74 \\
\hline
\end{tabular}

b. Menentukan Momen Inersia Bidang Z-Y Pada Sumbu Z (Iz)

Tabel 4.11. Nilai Momen Inersia bidang Z-Y pada sumbu Z

\begin{tabular}{|c|c|c|c|c|c|}
\hline Node & $\mathrm{L}(\mathrm{mm})$ & $\mathrm{Z}(\mathrm{mm})$ & $\mathrm{Y}(\mathrm{mm})$ & $\mathrm{Iz}$ & Hasil $\left(\mathrm{mm}^{3}\right)$ \\
\hline $1000-40$ & 578.50 & 1334.31 & -208.78 & $L^{3} / 12+L Z^{2}$ & 1046077820.87 \\
\hline $40-50$ & 1290.00 & 1334.31 & -853.78 & $L^{3} / 12+L Z^{2}$ & 2475568644.42 \\
\hline $50-60$ & 2536.30 & 1334.31 & -208.78 & $L^{3} / 12+L Z^{2}$ & 5875183225.29 \\
\hline $60-70$ & 2870.00 & 2769.31 & -208.78 & $\mathrm{LY}^{2}$ & 125103461.81 \\
\hline $70-90$ & 4108.00 & 1334.31 & -208.78 & $L^{3} / 12+L Z^{2}$ & 13090864162.25 \\
\hline $90-110$ & 3761.00 & 6084.81 & -208.78 & $L Y^{2}$ & 163942202.04 \\
\hline $110-200$ & 1333.00 & 1334.31 & -2165.28 & $L^{3} / 12+L Z^{2}$ & 2570616577.31 \\
\hline Total & & & & & 25347356094.00 \\
\hline
\end{tabular}

c. Menentukan Momen Inersia Bidang Z-Y Pada Sumbu Y (Iy)

Tabel 4.12. Nilai Momen Inersia bidang Z-Y pada sumbu Y

\begin{tabular}{|c|r|r|r|r|r|}
\hline Node & \multicolumn{1}{c|}{$\mathrm{L}(\mathrm{mm})$} & \multicolumn{1}{c|}{$\mathrm{Z}(\mathrm{mm})$} & \multicolumn{1}{c|}{$\mathrm{Y}(\mathrm{mm})$} & \multicolumn{1}{c|}{$\mathrm{Iy}$} & \multicolumn{1}{c|}{ Hasil $\left(\mathrm{mm}^{3}\right)$} \\
\hline $1000-40$ & 4442.10 & 1334.31 & -208.78 & $\mathrm{~L}^{3} / 12+\mathrm{L} \mathrm{Y}^{2}$ & 7498017925.32 \\
\hline $40-50$ & 2003.00 & 1334.31 & -853.78 & $\mathrm{LZ}^{2}$ & 3566082032.96 \\
\hline $50-60$ & 23358.40 & 1334.31 & -208.78 & $\mathrm{~L}^{3} / 12+\mathrm{LY}^{2}$ & 1063075687749.67 \\
\hline $60-70$ & 2600.00 & 2769.31 & -208.78 & $\mathrm{~L}^{3} / 12+\mathrm{LY}^{2}$ & 1578000813.25 \\
\hline $70-90$ & 3514.00 & 1334.31 & -208.78 & $\mathrm{~L}^{3} / 12+\mathrm{L} \mathrm{L}^{2}$ & 3769138853.45 \\
\hline $90-110$ & 1359.00 & 6084.81 & -208.78 & $\mathrm{~L}^{3} / 12+\mathrm{LY}^{2}$ & 268398159.87 \\
\hline $110-200$ & 4201.00 & 1334.31 & -2165.28 & $\mathrm{LZ}^{2}$ & 7479336305.77 \\
\hline Total & \multicolumn{7}{|c}{} & & 1087234661840.29 \\
\hline
\end{tabular}

Dari hasil perhitungan diatas didapat disimpulkan nilai momen inersia pada sistem perpipaan yang diproyeksikan pada bidang X-Y, X-Z, dan Z-Y adalah sebagai berikut:

- Momen inersia bidang X-Y (Ixy): $9481807477,03 \mathrm{~mm}^{3}$

- M omen inersia bidang X-Z (Ixz): $75925271272,51 \mathrm{~mm}^{3}$

- M omen inersia bidang Y-Z (Iyz): -$13770288215,74 \mathrm{~mm}^{3}$

Sedangkan untuk momen inersia pada 3 sumbu $X$, $\mathrm{Y}$, dan $\mathrm{Z}$ dari perhitungan di atas diperoleh:

- M omen inersia terhadap sumbu X (Ix): 48477226311,66 $\mathrm{mm}^{3}$

- Momen inersia terhadap sumbu Y (Iy): $1107367059666,69 \mathrm{~mm}^{3}$

- Momen inersia terhadap sumbu Z (Iz): $110248038753,11 \mathrm{~mm}^{3}$

- Momen inersia I : 342005,45 mm

- Panjang total pipa yang berada searah dengan sumbu X $(L x)=5556 \mathrm{~mm}$

- Panjang total pipa yang berada searah dengan sumbu Y $(L y)=2533 \mathrm{~mm}$

- Panjang total pipa yang berada searah dengan sumbu Z $(L z)=6001 \mathrm{~mm}$

Perhitungan Pertambahan Panjang Pipa Pada Sumbu X, Y, Z

Pertambahan panjang pada sumbu $X$

$$
\begin{aligned}
\Delta x & =\frac{\alpha}{1200 \mathrm{in}} \times L x \\
& =0,00242 \mathrm{~mm} \times 5556 \mathrm{~mm} \\
& =13,44552 \mathrm{~mm}
\end{aligned}
$$

$\Delta x . E . I=13,44552 \mathrm{~mm} \times 19643 \mathrm{~kg} / \mathrm{mm}^{2} \times 342005,45 \mathrm{~mm}^{4}$ $=90327178882,52 \mathrm{~kg} \cdot \mathrm{mm}^{3}$

Pertambahan panjang pada sumbu $Y$

$$
\begin{aligned}
\Delta y & =\frac{\alpha}{1200 \mathrm{in}} \times L y \\
& =0,00242 \mathrm{~mm} \times 2533 \mathrm{~mm} \\
& =6,129 \mathrm{~mm}
\end{aligned}
$$

Ay.E. $I=6,129 \mathrm{~mm} \times 19643 \mathrm{~kg} / \mathrm{mm}^{2} \times 342005,45 \mathrm{~mm}^{4}$

$$
=41180479501,34 \mathrm{~kg} \cdot \mathrm{mm}^{3}
$$

Pertambahan panjang pada sumbu $Z$

$$
\begin{aligned}
\Delta z & =\frac{\alpha}{1200 \mathrm{in}} \times L z \\
& =0,00242 \mathrm{~mm} \times 6001 \mathrm{~mm} \\
& =14,522 \mathrm{~mm}
\end{aligned}
$$

$\Delta z . E . I=14,522 \mathrm{~mm} \times 19643 \mathrm{~kg} / \mathrm{mm}^{2} \times 342005,45 \mathrm{~mm}^{4}$

$$
=97561807140,75 \mathrm{~kg} \cdot \mathrm{mm}^{3}
$$

\section{Perhitungan Gaya yang Bekerja Pada Sumbu} $\mathbf{X}, \mathbf{Y}, \mathbf{Z}$ 
Maka untuk menemukan jumlah gaya yang bekerja pada sumbu $\mathrm{X}, \mathrm{Y}$, dan $\mathrm{Z}$ di gunakan metode eliminasi dan subsitusi, di bawah ini hasil perhitungannya.

Besar gaya pada sumbu $\mathrm{X}=28,88 \mathrm{~kg}$

Besar gaya pada sumbu $Y=6,28 \mathrm{~kg}$

Besar gaya pada sumbu $Z=6,74 \mathrm{~kg}$

Tabel 3.16. Nilai Momen Tekuk dan Momen Torsi pada node 88

\begin{tabular}{|c|c|c|c|}
\hline Nod & Bidang X-Y & Bidang X-Z & Bidang Y-Z \\
\hline \multirow{4}{*}{88} & $\begin{array}{c}283.21 \mathrm{Nx}(10.032 \mathrm{~m}) \cdot 66.096 \\
\mathrm{Nx}(-10.20 \mathrm{~m})\end{array}$ & $\begin{array}{c}283.21 \mathrm{Nx}(13.65 \mathrm{~m}) \cdot 66.09 \mathrm{~N} \\
\times(1.596 \mathrm{~m})\end{array}$ & $\begin{array}{l}66.096 \mathrm{Nx}(0.209 \mathrm{~m}) \cdot \\
66.09 \mathrm{Nx}(0.044 \mathrm{~m})\end{array}$ \\
\hline & $\mathrm{M}_{\mathrm{m}}=3515.38272 \mathrm{Nm}$ & $\mathrm{M}_{\mathrm{b}}=3760.3209 \mathrm{Nm}$ & $\mathrm{M}_{\mathrm{m}}=10.9065 \mathrm{Nm}$ \\
\hline & \multirow{2}{*}{\multicolumn{2}{|c|}{$\mathrm{Mt}=3315.38272 \mathrm{Nm}$}} & $\mathrm{Mb}=3760.3209 \mathrm{Nm}$ \\
\hline & & & Resultan $M_{6}=5147.613907 \mathrm{Nm}$ \\
\hline
\end{tabular}

\begin{tabular}{|c|c|c|c|c|c|c|c|c|}
\hline Node & $\begin{array}{c}\text { Modulus } \\
\text { Penampang } \\
Z\left(\mathrm{~m}^{\prime}\right)\end{array}$ & $\begin{array}{c}\text { Momen } \\
\text { Bending }, \mathrm{I}_{\mathrm{b}} \\
(\mathrm{N}, \mathrm{m})\end{array}$ & $\begin{array}{c}\text { Momen } \\
\text { Torsi } \\
\text { ML } \\
(\mathrm{N}, \mathrm{m}) \\
\end{array}$ & $\begin{array}{c}\text { Tegangan } \\
\text { Bending } S_{b} \\
\left(\mathrm{~N} / \mathrm{m}^{2}\right)\end{array}$ & $\begin{array}{c}\text { Tegangangan } \\
\text { Toris } \mathrm{S}_{+} \\
\left(\mathrm{N} / \mathrm{m}^{\prime}\right)\end{array}$ & $\begin{array}{c}\text { Tegangan } \\
\text { Exspansi } S_{I} \\
\left(\mathrm{~N} / m^{2}\right)\end{array}$ & $\mathrm{N} / \mathrm{m}^{2}$ & Kpa \\
\hline 88 & 0.000342005 & 5147.613907 & 305.49 & 15051262.80 & 4466615.69 & 15077744.33 & 150777443.33 & 150777.443 \\
\hline
\end{tabular}

\section{Simulasi Tegangan Pipa Akibat Beban Ekspansi dengan Software CAESAR II}

Dari Pada software CAESAR II untuk tegangan pipa akibat Ekspansi terdapat pada node 88 dan besarnya pun dapat dilihat seperti ditunjukkan pada gambar 4.7

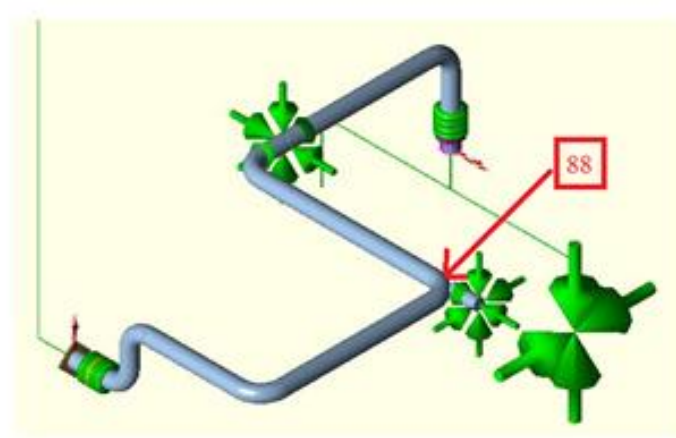

$\begin{array}{lccccc}\text { CODE STRESS CHECK PASSED } & \text { : LOADCASE } & 94 & \text { (EXP) } & \text { L94=L4-L9 } & \\ & & & & \\ \text { Highest Stresses: (KPa } & \text { ) LOADCASE } & 94 & \text { (EXP) } & \text { L94=L4-L9 } & \\ \text { Ratio (8) : } & 70.1 & \text { QNode } & 88 & \\ \text { Code Stress: } & 171999.0 & \text { Allowable Stress: } & 245527.7 \\ \text { Axial Stress: } & 26744.9 & \text { QNode } & 350 & \\ \text { Bending Stress: } & 154606.8 & \text { QNode } & 88 \\ \text { Torsion Stress: } & 6761.0 & \text { QNode } & 30 \\ \text { Hoop Stress: } & 0.0 & \text { QNode } & 20 \\ \text { Max Stress Intensity: } & 171999.0 & \text { CNode } & 88\end{array}$

\section{Evaluasi Perhitungan Tegangan Pipa dengan Program CAESAR II}

Dalam melakukan perhitungan dengan program CAESAR II didapat hasil output gaya, momen dan tegangan pipa pada saat sistem beroperasi, yang besarnya bervariasi sesuai dengan jenis material yang digunakan, besar temperatur, tekanan dan tingkat fleksibilitas jalur tersebut. Jadi tegangan maksimum hasil output perhitungan kalkulasi program CAESAR II pada tegangan Ekspansi di bawah ini.

Tabel 4.5. Nilai tegangan pada pipa 043-GN31004/T08

\begin{tabular}{|l|c|c|c|c|}
\hline \multicolumn{1}{|c|}{ Load Case } & Node & $\begin{array}{c}\text { Calculation } \\
\text { Stress } \\
\left(\mathbf{K g / \mathbf { c m } ^ { 2 } )}\right.\end{array}$ & $\begin{array}{c}\text { Allowable } \\
\text { Stress } \\
\left(\mathbf{K g} / \mathbf{c m}^{2}\right)\end{array}$ & $\begin{array}{c}\text { Ratio } \\
(\%)\end{array}$ \\
\hline 1 (HYD) WW+HP+H & 275 & 563.3 & 2214.4 & 25.4 \\
\hline 2 (EXP) L94=L4-L9 & 88 & 171999 & 245527.7 & 70.1 \\
\hline 3 (EXP) L95=L5-L9 & 88 & 225596.8 & 243978.4 & 92.5 \\
\hline 4 (EXP) L96=L6-L9 & 88 & 174089.5 & 245527.7 & 70.9 \\
\hline
\end{tabular}

\section{Evaluasi Perhitungan Tegangan Pipa Akibat Beban Ekspansi pada Program CAESAR dan Perhitungan Manual}

Berdasarkan acuan standar ASME B31.3, besar dan titik terjadinya tegangan maksimum pada sistem perpipaan akibat beban ekpansi pada program CAESAR seperti terlihat pada Tabel 4.16 dibawah ini.

Tabel 4.16. Nilai tegangan akibat Beban Ekspansi
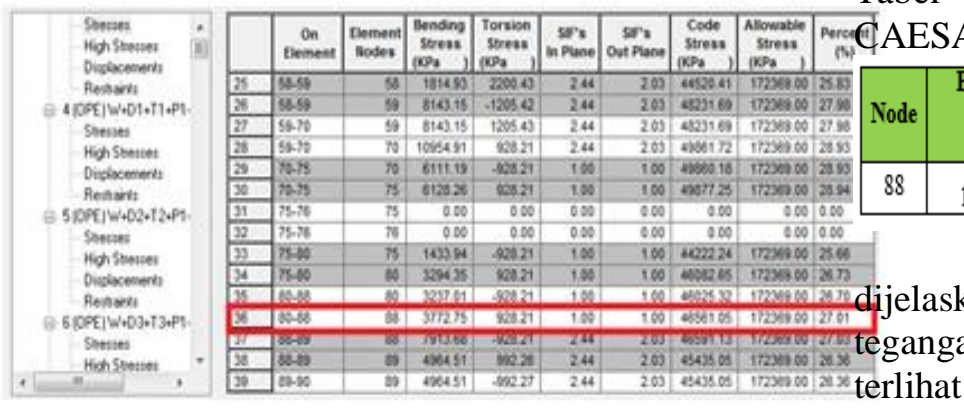

\begin{tabular}{|c|c|c|c|c|c|}
\hline Node & $\begin{array}{c}\text { Bending } \\
\text { Stress } \\
(\mathrm{KPa})\end{array}$ & $\begin{array}{c}\text { Torsion Stress } \\
(\mathrm{KPa})\end{array}$ & $\begin{array}{c}\text { Expansion Load } \\
(\mathrm{KPa})\end{array}$ & $\begin{array}{c}\text { Allowable } \\
\text { Stress } \\
(\mathrm{KPa})\end{array}$ & Ratio (\%) \\
\hline 88 & 17391.2 & 279.9 & 171999 & 245527.7 & 70.1 \\
\hline
\end{tabular}

Dari hasil perhitungan manula yang telah kan sebelumnya, maka diperoleh nilai gangan maksimum akibat beban ekspansi. Seperti Tabel 4.17. Perbandingan Nilai Tegangan Maksimum Beban Ekspansi Program CAESAR II dengan Perhitungan Manual 


\begin{tabular}{|c|c|c|c|c|c|}
\hline Node & $\begin{array}{c}\text { Program } \\
\text { CAESAR } \\
\text { II }(\mathrm{KPa})\end{array}$ & $\begin{array}{c}\text { Perhitungan } \\
\text { Manual } \\
(\mathrm{KPa})\end{array}$ & $\begin{array}{c}\text { Deviasi } \\
\text { Perhitungan } \\
(\%)\end{array}$ & $\begin{array}{c}\text { Allowable } \\
\text { Stress } \\
(\mathrm{KPa})\end{array}$ & Status \\
\hline 88 & 171999 & 150777.4433 & $12.34 \%$ & 245527.7 & OK \\
\hline
\end{tabular}

\begin{tabular}{|c|c|c|c|c|c|}
\hline Node & $\begin{array}{c}\text { Program } \\
\text { CAESAR } \\
\text { II }(\mathrm{KPa})\end{array}$ & $\begin{array}{c}\text { Perhitungan } \\
\text { Manual } \\
(\mathrm{KPa})\end{array}$ & $\begin{array}{c}\text { Deviasi } \\
\text { Perhitungan } \\
(\mathrm{KPa})\end{array}$ & $\begin{array}{c}\text { Allowable } \\
\text { Stress (KPa) }\end{array}$ & Status \\
\hline 88 & 171999 & 150777.4433 & 21221.56 & 245527.7 & OK \\
\hline
\end{tabular}

Besarnya tegangan akibat beban ekspansi pada node 88 dari hasil perhitungan Program CAESAR II adalah sebesar $171999 \mathrm{KPa}$ dan dari hasil perhitungan Manual adalah sebesar $150777,4433 \mathrm{KPa}$ dengan deviasi perhitungan dari kedua metode tersebut adalah $12,34 \%$, dimana tegangan yang terjadi pada sistem tidak melebihi batasan yang ditetapkan oleh standar sehingga sistem perpipaan dinyatakan dalam batas aman untuk beroperasi.

Secara keseluruhan nilai tegangan akibat beban ekspansi tidak melebihi batas tegangan yang diizinkan oleh material dari standar ASME B31.3 sebesar 245527,7 KPa. Terjadinya deviasi perbedaan nilai tersebut dikarenakan pada program CAESAR II perhitungan gaya serta momen dilakukan dengan metode finite element sehingga mampu menghitung lebih mendetail, sedangkan pada perhitungan manual menggunakan teori-teori perhitungan yang bersifat umum.

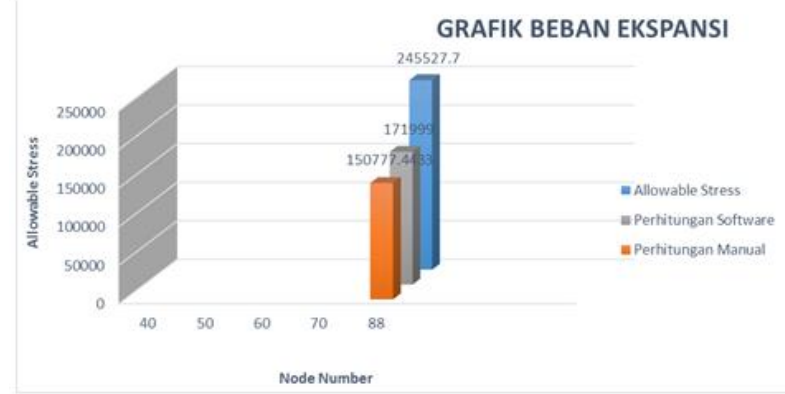

Gambar 4.9. Grafik perbandingan nilai Ekspansi load manual dan Software

(Sumber : Program Office 2013)

\section{KESIMPULAN}

Berdasarkan hasil perhitungan tegangan pada sistem perpipaan Line 043-GN-31004/T08 dapat disimpulkan sebagai berikut:

1. Nilai tegangan yang diakibatkan beban Ekspansi (SE) yang tertinggi baik dari hasil perhitungan program CAESAR II ataupun perhitungan Manual terjadi pada node 88. Yaitu sebesar $171999 \mathrm{KPa}$ (CAESAR II) dan 150777.4433 $\mathrm{KPa}$ (Perhitungan Manual) dari hasil perhitungan secara keseluruhan nilai tegangan akibat beban ekspansi tidak melebihi batas tegangan yang diizinkan oleh material dari standar ASME B31.3 sebesar 245527.7 KPa sehingga sistem perpipaan dinyatakan dalam batas aman untuk beroperasi.

2. Deviasi hasil perhitugan maksimum dari tegangan akibat beban Ekspansi Thermal antara perhitungan program CAESAR II dan perhitungan manual sebesar $21221.56 \mathrm{KPa}$ atau sebesar $12.34 \%$.

Dikarenakan Fluida pada pipa tersebut adalah natural Gas, maka dilakukan perencanaan ulang jalur pipa dan mengganti spesifikasi pada material dengan menggunakan material Duplex sehingga hasil analisa pada perencanaan pipa sesuai dengan yang di harapkan.

\section{DAFTAR PUSTAKA}

American Society of Mechanical Engineers. ASME B31.1, Power Piping. ASME International. 2012.

Rhea, Robert. A and Parisher, Roy A. "Pipe Drafting And Design", Second Edition, Gulf Profesional Publishing, 2002.

Agustinus, Donny, Pengantar Piping Stress Analysis dengan Caesar II. Jakarta: Entry Augustino Publisher, 2009

Raswari, "Perencanaan Dan Penggambaran Sistem perpipaan", Penerbit Universitas Indonesia, UI - Press, Jakarta, 2007.

Tri Adi Siswanto, Hari Prastowo, dan Beni Cahyono, 2014, Tegangan Pipa : Analisa Pengaruh Water Hamer Terhadap Nilai Stress Pipa Pada Sistem Loading-Offloading PT.DABN, Surabaya: JURNAL TEKNIK POMITS, Vol.3, No.1: hal.142-148

Prof. Dr. Ir. Dahmir Dahlan, MSc. 2016. Analisis Tegangan Perpipaan. Jakarta: Sekolah Pascasarjana ISTN.

Liang - Chuan (L.C.) Peng, and Tsen Loong (Alvin) Peng, "Pipe Stress Engineering", Peng Engineering, ASME Press, New York, 2009.

Jamaludin, Achmad, 2016, Analisis Tegangan Sistem Perpipaan Pada Sisi Tekan Pompa P003E Menggunakan Caesar 2 dan Perhitungan Manual, Jurusan Teknik Mesin, Institut Sains dan Teknologi Nasional, Jakarta.

ITT Grinnell Industrial Piping "Piping Design and Engineering", $7^{\text {th }}$ Edition, Inc., ITT Grinnell Corporation, USA, 1995. 